\title{
Iceland's meltdown: the rise and fall of international banking in the North Atlantic
}

\author{
ROBERT H. WADE \\ SILLA SIGURGEIRSDOTTIR*
}

\begin{abstract}
"Iceland should be a model to the world" (Arthur Laffer, November 2007)

"They [the Icelandic banks] shouldn't be worried about the fundamental soundness of their business model. I think it is very sound and very good"
\end{abstract}

(Richard Portes, May 2008)

This paper shows how rapid privatization and liberalization of Iceland's small local banks around 2000, combined with well-developed crony relations among the elite, enabled a small group of financiers to leverage government-guaranteed deposits into a vast wave of mergers and acquisitions abroad, and redistribute enough of the profits back home to make the economy boom. Negative policy feedback loops were systematically undermined. The incoming left-wing government, with IMF support, has managed to protect the bulk of the population from the worst of the effects.

Key words: Iceland; financial crisis; privatization; banking crisis.

JEL Classification: E5

In 2007 average income in Iceland was almost $\$ 70,000$, about the fifth highest in the world and 1.6 times that of the United States. Reykjavik's shops brimmed with luxury goods, its restaurants made London look cheap, and sports utility vehicles (SUVs) choked its narrow streets. Icelanders were the happiest people in the world according to an international study in 2006, just ahead of Australians.

\footnotetext{
* Robert Wade is professor of political economy at the London School of Economics, E-mail: r.wade@ lse.ac.uk.. Silla (Sigurbjorg) Sigurgeirsdottir is lecturer in public policy analysis at the University of Iceland,.E-mail: s.sigurgeirsdottir@simnet.is. Submitted: 21/Dec./2010; Approved: 23/Feb./2011.
} 
They also enjoyed the least corrupt public administration in the world, according to Transparency International's Corruption Perceptions index, an honour shared with New Zealand and Finland in 2007. They had a life expectancy at birth of 80.8 years by 2008 , putting them $11^{\text {th }}$ in the world (well above the US at 78.2 years and the UK at 79.9 though well below Japan at 82.2 years). The prison population per 100,000 was 60 , lowest in the world (equal with Japan and Finland).

What was there not to like about this model? Iceland's boom began in 2001 after the US Federal Reserve began cutting interest rates and pumping cheap money into the global economy. At about this time the Icelandic government privatized what had been small "utility"-oriented banks and set them free, much as the US government liberalized the Savings and Loans banks in the 1980s. The new banks discovered the alchemy of borrowing cheaply abroad, buying assets abroad, and then transforming the revenue streams into dramatically higher profits, wages, tax revenues and political support at home. Within only six years or so three Icelandic banks, with no prior experience of international banking, shot into the league of the world's 300 biggest banks. Looking only at the results and overlooking how they were being achieved, just about everyone applauded while the borrowing lasted. Clever people streamed into finance, too few served the state. The politicians, regulators and most economists thought that all they had to do was keep out of the way while the financiers performed their magic. Of course, much the same happened in the US, Britain, and Ireland. But Iceland stands out from the other cases as a more transparent illustration of how "masters of the universe" confidence, sophistic ideology, mercenary gain, mendacity and sheer ignorance combined to drive the boom and bust.

\section{FROM RAGS TO RICHES, AND THE EMERGENCE OF INTERNATIONAL BANKING}

Iceland's prosperity developed from an economy which was about the poorest in Western Europe at the end of the Second World War, and which for most of the post-war period was more regulated, politicized and inward looking than its European neighbours. Its fast economic growth - especially between 1960 and 1980 - was driven by a combination of Marshall Plan aid; an abundant export commodity with the unusual property of a high income elasticity of demand - coldwater fish; a foreign-exchange earning US/NATO military base which was large relative to the rest of the economy; and a small population (about 300,000 as of the mid 2000s), with a high average level of education, a Lutheran work ethic, and a strong sense of national identity rooted in the Icelandic language and literature.

Through the second half of the twentieth century a bloc of some 14 families (popularly known as the "Octopus" ${ }^{1}$ ) constituted the economic and political establishment, based in fishing, transport, oil importing and distributing, provisioning

\footnotetext{
1 Árnason, 1991.
} 
the NATO base, and domestic banking and insurance. This establishment provided the leaders of the two political parties which formed most of the coalition governments since the 1930s, and which divided up the spoils of office between core supporters. The dominant party was always the Independence (conservative) party, allied most of the time with the much smaller Progressive (agrarian) party. Occasionally social democrats and communists got a look in. Oligopoly and monopoly characterised the economy until the 1990s.

In the 1970s a dozen or so men studying law or business administration at the University of Iceland formed a group to promote neoliberal ideas, and took over the editorship of a journal called "The Locomotive". As they moved into positions of influence and power they remained a network of mutually-promoting friends, more loyal to each other than to the organizations for which they worked. Known as the Locomotive group, they constituted a segment of Iceland's "shadow elite", using their influence in the Independence party and other organizations to win opportunities for themselves and refashion the society as a neoliberal model (far from the norms of Nordic social democracy, which they disparaged $)^{2}$. Several of them stepped out of the shadows into the limelight, taking the top political and juridical positions.

Of these David Oddsson was the chieftain. A life-long politician with a law degree and virtually no experience of the world beyond Iceland, he reigned as prime minister for 14 years, from 1991 to 2004. His big agenda was privatization and deregulation (followed by some re-regulation in line with the requirements of the European Economic Area, which Iceland joined in 1993). He invoked Thatcher's Britain, Reagan's America, and Lange's New Zealand as his model.

Oddsson and his followers expected that they could use state power to steer the newly privatized profit opportunities to themselves, under the banner of the free market. But things did not quite work to plan. The reforms opened up opportunities for a third set of families which had been outside the establishment and the Locomotive group. Some had earlier got rich from retailing (which was not controlled by the establishment and was an excellent cash cow because the owners received cash on sale but did not pay suppliers for 90 days). Others had got rich from running businesses in post-communist Russia, and still others by obtaining fishing quotas through cronyistic connections to the Independence party when the quotas were handed over to them for free in the 1980s.

In the period 1998-2002 the government privatized the two major state-owned banks and fostered the creation of a third big bank from mergers with smaller ones. It excluded foreign buyers, and favored nationals with good connections in the Independence Party and the Progressive Party, the governing coalition at the time. However, several players from beyond the establishment also became major bank shareholders, using their new riches from retailing, fishing, and Russia. The new owners and their family members and friends set up private equity companies alongside their banks (such as FL Group, Exista, Novator, Baugur). Few of them had much experience in national banking, let alone international finance.

The bank owners proceeded to take out giant loans from the banks for their

${ }^{2}$ Wedel, 2009. 
direct use, using their shares as collateral; and also to make giant loans to their private equity companies. The bank owners and the equity companies used the loans to buy assets, some at inflated values; then used these assets as collateral for more giant loans; and bought more assets. To the ignorant or uncurious all this looked like it was strengthening the balance sheets of both parties.

What came to be known as "love letters" (mere promises) illustrates some of the alchemy. Icelandic bank A took a loan of KR 1 bn from Icelandic bank B. Bank A then made a reciprocal loan of KR 1 bn to bank B. No cash exchanged hands; the loans were book entries not backed by collateral. Bank A then used its loan to $\mathrm{B}$ as collateral for a loan from the Bank of Luxembourg. But now Bank A got real cash. Bank A entered the loan on the liabilities side of its balance sheet, and put it to work on the assets side to buy more assets. Using love letters, and making full use of Basel 2 rules to slide assets into categories against which they were required to hold less capital (allowing them higher leverage), the Icelandic banks were able to grow their assets at $50 \%$ a year and more, channelling some of the surging profits back into retained earnings and shareholder equity - thus enlarging the base for still faster asset growth.

The alleged illegality was in the first part of the love letter process - where the two banks made loans to each other not backed by collateral. But even with collateral the practice made the Icelandic banks heavily interdependent, such that if one went down the others would likely follow.

By such tactics, tiny Iceland's three main banks joined the ranks of the world's biggest 300 banks in 2006. On the back of their booming businesses the owners and managers took out more and more remuneration for themselves, accruing a skyrocketing share of national income for themselves. Their private jets took off and landed at the Reykjavik domestic airport, providing visual and auditory reminders to the part-admiring, part-jealous population below. They made generous loans to selected politicians; and bought controlling shares in media companies. The governing elite became their cheer leaders, boosting them internationally as "our go-getting Vikings". In gratitude for their support the government shifted the tax burden from the very top to the bottom half of the income scale, in order to strengthen "incentives for risk taking" 3

The government, the banks, the Chamber of Commerce and other entities mounted a well-orchestrated campaign to project Iceland as an emerging international financial centre conveniently mid-way between Europe and America ${ }^{4}$. The leading Icelandic champion of free market economics declared in the Wall Street Journal in 2004, "David Oddsson's experiment with liberal policies is the greatest success story in the world" 5 . The Iceland Chamber of Commerce declared in February 2006, in chillingly hubristic words:

\footnotetext{
${ }^{3}$ Ólafsson and Kristjánsson, 2010.

${ }^{4}$ Burt, 1998.

${ }^{5}$ Gissurason, 2004.
} 
In public debate [in Iceland] it is often said that things are not as good as in our neighbouring countries. The other Nordic countries are the reference point $[\ldots]$ The Chamber of Commerce suggests that Iceland stop comparing itself with the other Nordic countries, after all we are in many ways superior to them ${ }^{6}$.

\section{WORRIES BEGIN TO BE VOICED ABOUT FINANCIAL STABILITY}

In early 2006 the international media started to report worries about the stability of the banks, and the banks started to have problems raising money in the money markets.

The country had built up eye-popping imbalances. The current account deficit was close to the biggest in the world, at $24 \%$ of GDP in 2006. The stock market shot up 9 times between 2001 and 2007, which must be near a world record. The consolidated "assets" of its three main banks jumped from 1.7 times GDP in 2003 to almost 9 times GDP by end 2007, second in the world after Switzerland (enough to elevate all three into the ranks of the world's 300 biggest banks). They were operating far beyond the capacity of the central bank to support them as lender- or marketmaker of last resort - all the more so because their liabilities were real but many of their assets were dubious, and a high proportion of both were in foreign currencies.

During what came to be known as the 2006 "mini-crisis" the krona fell sharply, the costs of banks' liabilities in foreign currencies rose, and the sustainability of debts in foreign currencies became a "public" problem. Business defaults increased, and state bonds suffered a downgrade by credit rating agencies.

The IMF rang the alarm bell in its country report on Iceland in 2006. The watered-down public version said that

international markets are concerned that this pace of growth [of bank balance sheets] has exposed the Icelandic financial system to vulnerabilities that could undermine its health as the economy adjusts to restore balance. Potential vulnerabilities include considerable near-term refinancing needs, credit quality, the long-term sustainability of the banks' presence in the domestic mortgage market, and the crossholdings of equity ${ }^{7}$.

The private version was much more critical. But the prime minister and finance minister insisted it be toned down before publication, and the IMF complied. For example, the private version described Iceland's imbalances as "staggering", which was changed in the public version to "remarkable".

Several Icelandic and foreign economists warned of big dangers ahead. A

\footnotetext{
${ }^{6}$ Vidskiptathing Ìslands 2015, report published by Icelandic Chamber of Commerce, February 2006, emphasis added. Albert Einstein's dictum, "Imagination is more important than knowledge”, is emblazoned on the title page of this report.
}

${ }^{7}$ IMF, 2006. 
Danish bank wrote a critical report describing Iceland as a "geyser economy" (on the point of exploding like a geyser $)^{8}$.

\section{THE BANKERS AND THE GOVERNMENT DEFINE THE PROBLEM AS A LACK OF RELIABLE INFORMATION}

However, the Icelandic bankers and politicians interpreted the so-called "mini crisis" of 2006 as the result of a lack of information about the banks, a mere problem of reputation. And they calculated that any tightening of regulation at this time would be interpreted as confirming that the media were right to be talking about a problem. So the central bank simply took out a loan to double the foreign exchange reserves, while the bankers and the government mounted a big PR campaign. The banks continued with a huge mismatch between their assets denominated in foreign currencies (mostly illiquid and long maturities) and their liabilities denominated in foreign currencies. By the end of 2007 the three main banks obtained two thirds of their total funding from short-term borrowings.

As part of the PR campaign the Iceland Chamber of Commerce commissioned a report on the financial system from the American monetary economist Professor Frederic Mishkin and an Icelandic economist, published in May 2006. Only some 30 pages long, it affirmed the stability of the banks, in marked contrast to the IMF report written at the same time ${ }^{9}$. The Chamber paid Mishkin $\$ 135,000$. The following year the Chamber commissioned another report from Professor Richard Portes of the London Business School and a second Icelandic economist, published in November 2007. They affirmed - with more qualifications - the international stability of the Icelandic banks, hardly engaging with the IMF's arguments ${ }^{10}$. They left the lender-of-last resort question to the end of their 65 page report, and dismissed it in half a page. The Chamber paid Portes $£ 58,000$ (sterling), around the annual salary of an associate professor at a UK university. From the Chamber's point of view buying Mishkin's and Portes's names was good investment because their imprimatur could be used to keep the party going despite the IMF-type negative reports. The politicians and regulators were the more easily convinced because Oddsson had abolished the National Economic Institute in 2002, leaving the domestic system with little capacity to produce independent analysis.

A long line of libertarian ideologues were invited to Iceland to preach the gospel of neoliberal economics. One such was Arthur Laffer, the supply-side economist of the Reagan era, who in late 2007 assured the Icelandic business and libertarian community that fast economic growth with a large trade deficit and bal-

\footnotetext{
${ }^{8}$ Danske Bank, 2006.

${ }^{9}$ Mishkin and Herbertsson, 2006.

${ }^{10}$ Portes and Baldursson, 2007.
} 
looning foreign debt were signs of success. "Iceland should be a model to the world", he declared ${ }^{11}$. Little did he know.

Debt became the way to live. Brokers criss-crossed the country persuading households to load up on more debt and convert existing krona debt into much lower interest Swiss franc- or Japanese yen-denominated debt ${ }^{12}$. "The krona would have to fall by more than $20 \%$ for this not to be a no-brainer", they told their clients, "and that's not going to happen".

\section{ICESAVE AND REGULATORY CAPTURE}

Despite surviving the 2006 mini crisis, the banks continued to have difficulties raising money to fund their asset purchases and repay existing debt. Indeed, auditor reports written in 2010 for the special prosecutor (see below) show that at least two of the banks were insolvent by 2007, but kept going with extremely expensive credit lines from foreign banks. The reports attest to fraud inside the banks and negligence on the part of the banks' auditor (PWC) ${ }^{13}$.

As borrowing from other banks became more difficult the big three faced the prospect of ending up like beached whales. One of them hit on the idea of saving itself by raising retail deposits in Britain (October 2006) and Holland (May 2008). It set out to do so via internet branches in which depositors got a higher interest rate than from their own high street banks. Icesave, as the branches were called, vacuumed up deposits directed by "best buy" internet sites, including tens of millions of pounds sterling from such organizations as Cambridge University, the London Metropolitan Police Authority, and most remarkable of all, the UK Audit Commission (responsible for auditing the activities of local governments). The inflood allowed the bank to repay its loans and buy more assets. The fact that the Icesave entities were legally established as "branches" rather than "subsidiaries" meant that they were to be supervised by the Icelandic authorities, not by the host authorities. The owners were keen to establish them as branches rather than subsidiaries because this gave them more scope to transfer capital and deposits across borders.

In March 2008, as more evidence came into government bodies pointing to looming catastrophe in the banks, the government launched yet another PR campaign in the form of a "road-show" in New York, where the Prime Minister assured Wall Street that the Icelandic banks were sound despite rumours to the contrary. The foreign minister and Professor Richard Portes held a road-show in Copenhagen to give the same assurance. In the run-up to the opening of the Icesave branch in Holland in May 2008 the parent bank published a prospectus which carried an

\footnotetext{
${ }^{11}$ Laffer, 2007.

12 The Supreme Court ruled in June 2010 that much of this activity was illegal, according to legislation passed by parliament in 2001. That it nevertheless continued for at least seven years illustrates the gap between laws and practice in the Icelandic financial industry, and the feebleness of supervision by the Financial Services Authority.

${ }^{13}$ One of the reports is COFISYS, "Glitnir bank: Investigation in the accounts and the auditor's files: Report to the special prosecutor”, November 2010.
} 
interview with the chairman of Iceland's Financial Supervisory Authority, affirming that all was well with Iceland's banks. The government's PR road shows, and the chairman's granting of the interview for PR purposes, illustrate the regulatory capture that was endemic in Iceland's system of financial management.

\section{INTERNATIONAL ATTEMPTS TO RESCUE THE BANKS}

Though the prime minister, the foreign minister, Richard Portes and the chairman of the regulators appeared unaware that Iceland was fast approaching crisis, the IMF was only too aware. In mid April 2008 it sent a confidential report to the government about what to do to rein in the banking system and save the economy. Mervyn King, governor of the Bank of England, offered David Oddsson (by then self-appointed chairman of the Central Bank of Iceland) help to scale down the banking system in late April 2008; but Oddsson did not even reply. The central bank had concluded it was impossible to scale down the banking system, and sought instead to borrow still more foreign exchange reserves. In mid May the central banks in Denmark, Sweden and Norway finally agreed credit lines, but on condition that three ministers and the three governors of the central bank sign a declaration written by the central banks of the three Nordic countries, promising to carry out a programme of actions very similar to that recommended by the IMF in mid April. The Icelanders agreed, without consulting or later informing the rest of the government or the Parliament ${ }^{14}$. Having got the credit lines they returned to business as usual. The Nordic central banks and the IMF grew increasingly exasperated, seeing the Icelanders as demanding and unreliable adolescents with a strong sense of entitlement.

Robert Aliber, an expert on financial crises, visited Reykjavik in June 2007 and counted the number of building cranes, after which he went on to predict, in a lecture at the University of Iceland, a big financial crisis within a year. In May 2008, on a return visit, he commented in a local newspaper that the FSA's level of competence (judging from his visit to it) was about equal to what would be achieved by random selection from the Reykjavik telephone directory.

Wade wrote an op-ed in The Financial Times on July $2^{\text {nd }}, 2008$, titled "Iceland pays the price for financial excess". Portes and collaborator replied in a long letter titled "Criticism of Icelandic economy does not square with the facts" (July $4^{\text {th }}$ ). They declared, "Robert Wade gets Iceland very wrong", and went on to assure readers that the financial system was stable. They said, "Iceland has had to apply exactly the same legislation and regulatory framework as European Union member states, and its Financial Services Authority is highly professional". They did not mention that the FSA had a total staff of 45 (a quarter of them lawyers) for regulating a financial system which included three mega-banks with assets then almost 9 times Iceland's GDP; nor did they mention that the central bank had almost no capacity to act as lender of last resort ${ }^{15}$.

\footnotetext{
${ }^{14}$ Special Investigation Commission, 2010, pp. 223-224.

${ }^{15}$ Drawing parallels with the East Asian/Russian/Brazilian crisis of 1997-1999, Wade gave several public
} 
Meanwhile some of the banks' biggest shareholders were themselves facing illiquidity or insolvency, which put the banks' own survival at risk. So in the few months before it folded Landsbanki (Icesave's parent) lent $36 \%$ of its capital to a few of its main owners. Glitnir passed on $17 \%$ of its capital ${ }^{16}$. On September $24^{\text {th }}$ Kaupthing's credit committee approved loans equal to more than $100 \%$ of the bank's equity, mainly to a few of its owners and closely connected parties ${ }^{17}$. As the saying goes, the best way to rob a bank is to own it.

\section{THE CRISIS HITS}

At the end of September 2008, in the wake of the Lehman collapse and seizure of money markets, the crisis finally hit. Remarkably, in the three days from October $1^{\text {st }}$ to October $3^{\text {rd }}$ UK local authorities poured in another $£ 33$ million into their Icesave accounts, as though their expensively paid finance directors were fast asleep. The next day the first bank collapsed, and within a week all had collapsed and been taken into public ownership. The instinct of those in charge was to protect the creditors and inject public funds to keep them afloat, as in many other countries, including the US and Ireland; but with assets by then equal to almost 11 times GDP, this proved impossible. Recievership was chosen faut de mieux.

From being among the 300 biggest banks in the world they now joined a less glorious league - Moody's list of the 11 biggest financial collapses in history.

In early October 2008 the Icelandic central bank, run by its chairman David Oddsson (the former prime minister), went crazy. Without consulting any of his staff he imposed a currency peg to a basket of currencies at close to the pre-crisis rate. His chief economist learned about it on the internet and threw up his hands in horror, exclaiming, "Oh no, now we are really going down the tubes!". The peg lasted only few hours, but time enough for cronies-in-the-know to spirit their money into other currencies. When it broke the krona sank like a stone. The central bank abruptly lowered the interest rate a week later, contributing to the sense of things out of control.

An IMF team arrived in October 2008 and prepared a crisis-management programme, the first time the IMF had been called in to rescue a developed economy since Britain in $1976^{18}$. To stabilize the krona it offered a loan of $\$ 2.5 \mathrm{bn}$. and

\footnotetext{
talks in Iceland from the summer of 2005 onwards about the build up of financial fragility, and was politely dismissed. Other warnings came from Willem Buiter and Anne Sibert. See their "The Icelandic banking crisis and what to do about it: The lender of last resort theory of optimal currency areas". Centre for Economic Policy Research (CEPR). Policy Insight No. 26. October 2008, which was presented to the commissioning bank in early 2008 but kept confidential. Available at: <http://www.cepr.org/pubs/ policyinsights/PolicyInsight26.pdf>. Also, see a report written by the Finish expert Kaarlo Jannari to the Prime Minister of Iceland in March 2009, "Report on banking regulation and supervision in Iceland: past, present and future”. Available at: <http://eng.forsaetisraduneyti.is/media/frettir/KaarloJannari_2009.pdf >. And Wade, "Iceland: wiser counsels should have prevailed", ft.com, October 14 $4^{\text {th }}, 2008$.

${ }^{16}$ Boyes, 2009, p. 160.

${ }^{17}$ Davidsdottir and Mason, 2011.

${ }^{18}$ IMF, 2008.
} 
the Nordic central banks, swallowing their anger, offered another $\$ 2.5 \mathrm{bn}$. The IMF approved stringent foreign exchange controls to stop capital from fleeing. It also called for an increase in the central bank interest rate from $15 \%$ to $18 \%$, but soon after reduced it to $15 \%$. Importantly, it called for no more than moderate fiscal tightening, with the main pain to come in 2010-2011. It helped the government begin to restructure and recapitalize the banking sector. By February 2009 the IMF had stationed staff members full time in Reykjavik. As head of office it chose a staff member who had been the room mate of the prime minister (Oddsson's successor) at Brandeis University in the 1970s.

The Icelandic krona (ISK) fell from about 90 to the euro at the start of 2008 to 190 in November 2008 - a massive cut in purchasing power. The foreign exchange market stopped working. Foreign exchange became available only for government approved imports. The stock market collapsed by about $98 \%$ in 2008 . By March 2009 the senior bonds of the banks were trading at between 2\% and $10 \%$ of their face value. Average gross national income fell from 1.6 times that of the United States in 2007 to 0.8 times in February 2009 (in market exchange rates). In krona terms, GDP (chained value) fell from the last quarter of 2008 to the end of 2010 by almost $10 \%$ (seasonally adjusted about $9.25 \%$ ). Unemployment rose from an average of $1.6 \%$ through $2008(4.8 \%$ in December) to an average of $8.1 \%$ in 2010 , rising to $8.5 \%$ in January 2011. Net migration went from an inflow during 2008 to an outflow of almost 4,500 in 2009 and 2,100 in 2010. As unemployment benefit comes to an end in 2011 outmigration is expected to increase.

\section{THE POLITICAL BACKLASH}

From the normally placid and consumption-obsessed population an anxious, angry protest movement emerged. A handful of organizers, mainly people like singers, writers and theatre directors who had been outside politics, called for rallies in the main square in front of the parliament building to demand a change of government. Thousands of people, all age groups and distinctly middle-class, assembled in shoulder-to-shoulder numbers never seen before in Iceland. They spent freezing Saturday afternoons chanting, banging saucepans, and listening to speeches and songs. "Fuck Fucking Hell" was one of their slogans. They linked arms in a circle around the parliament building to block it up, and assaulted the building and the police with fruit and yogurt as they called for the government's resignation. Another group of organizers arranged for public meetings in Reykjavik's biggest theater every Monday evening to hear analyses of the situation, at one of which government ministers petulently took questions. For all the fear and anger the protestors also felt a sense of elated solidarity.

In the wake of what was called "the saucepan revolution", the Independence Party-Social Democratic Alliance government, in power since May 2007, resigned in January 2009, the first government in the world to resign because of the global crisis. Elections in April 2009 ushered in a fragile coalition of Social Democrats and Left-Greens. One of its central fissures has been how and whether to repay the crushing Icesave debt demanded of it by the British and Dutch governments, and 
how to repay the loan taken out by the central bank in 2006 to double the country's foreign exchange reserves, which matures in 2011. Still another is whether to join the European Union and the eurozone.

\section{WHAT EXPLAINS THE IMPLOSION?}

The Lehman collapse and resulting paralysis of money markets was the trigger. But a crash would have come anyway because of the giant structural imbalances, the overreaching of the financiers, and the vulnerability to reversal of short-term capital inflows - just the things which Miskin, Portes and many others overlooked or downplayed. In a way, the Lehman's collapse was a blessing since its knock-on effects burst the Icelandic bubble soon enough to prevent what - if things had continued for another 12 months - might have been the first complete bankruptcy of a modern nation, and attendant mass outmigration.

The bankers and their linked private equity firms might have been studying the book by William Black (2005) called The Best Way to Rob a Bank is to Own One: How Corporate Executives and Politicians Looted the Savings and Loan Industry. As Black said on a post-crisis visit to Iceland, their behaviour fit the four main criteria of "accounting control fraud". They "(a) grew like crazy, (b) made really, really bad loans with high yields, (c) were extraordinary leveraged, i.e., a lot of debt compared to equity, and (d) maintained no significant loss reserves" ${ }^{19}$.

However, in the end the responsibility lies with the government, the central bank and the regulators, and their failure to regulate at every turn. What is striking about the Icelandic bubble is how it went on growing year after year while the politicians and regulators remained convinced it was not a bubble - or at least not one they could or should do anything about. All the feedback loops from evidence of trouble to public action to reign in the banks were broken.

Hence the FSA was kept to a tiny size (45 staff by 2006) as the banks grew and grew, in the name of "light touch regulation". It did not matter, apparently, that supervision meetings at the FSA would be attended by two or three officials and an intimidating phalanx of financial analysts and lawyers from the bank.

And hence the "common sense" decision at the level of the government to rely primarily on the banks for analysis of the financial system. Afterall, the banks paid much better than the central bank or the regulatory authority, so they attracted the best talent. People joined the central bank or the FSA with the aim of learning enough to cross the street and join one of the banks. So why not rely on the analyses of the best talents? Oddsson's closure of the National Economic Institute in 2002 removed the only independent domestic source of analytical information (apart from a few ignorable economists in the university).

The Iceland Chamber of Commerce also took an active role, commissioning analyses from "independent" experts like Mishkin and Portes, whom it paid handsomely for their endorsements. Mishkin's and Portes' reports were both written largely by their

${ }^{19}$ Black, 2010. 
Icelandic collaborators, and they were paid largely for their names. Still, they both claimed to be experts in financial systems. They had access to the same data as the IMF, the Danish bank, Robert Aliber and the few Icelandic critics. Either they did not know how to analyse a bubble - in which case they took the money under false pretences; or they did know but ignored the signs of an advanced bubble because they accepted the Chamber's offer of money in return for the "right" conclusions.

At every turn, conflicts of interest were ignored. Indeed, conflicts of interest have been so endemic in the small Icelandic system that they are often not even recognized as such. Rather, they tend to be neutralized by being seen as mere "coincidences of interest", which therefore pose no societal problem ${ }^{20}$. So people tend to be strikingly nonchalance about regulatory capture. In the case of finance, the oversized banking system had been able to get its way with the government and make itself the gatekeeper of critical information without politicians registering a problem. And when outside experts, such as the IMF, did show them that they had a problem, they were able to dismiss their concerns by holding up reports from vested interests which said otherwise, much as the tobacco industry commissioned scientists to raise doubts about the link between smoking and lung cancer.

Finally, the civil service is established in such a way that each department has little independence from the minister. The permanent secretary (top civil servant in each department) is selected by the minister, often on the basis of one-on-one interviews with no one else present, sometimes from a short-list prepared by an outside consulting firm. There is no civil service commission to ensure merit recruitment. The permanent secretaries in effect have life-time jobs at that rank (except in egregious circumstances), and the system is populated by people who once made a good deal with a minister and now have to be found same-rank jobs somewhere, at home or abroad.

In this context one can understand what happened when in 2007 the inner circle of government could no longer ignore the evidence that the balance sheets of the banks might be cans of worms. The relevant ministers established a coordination committee of senior civil servants to monitor the situation and plan for a crisis. But the committee members, led by the permanent secretary of the prime minister's office, had no idea how to do such planning and they did not even try. The Special Investigation Commission determined that they never reported to ministers in a way that could be verified - thus allowing the latter to deny that they knew how serious the situation was becoming, and escape legal responsibility.

\section{CONCLUSION}

Iceland is the story of Icarus in modern dress. Icarus sought to escape from exile in Crete using a pair of wings fashioned from feathers and wax. He was warned not to fly too close to the sun. But overcome by the excitement of flying, he flew too close, the wax melted, and he tumbled into the sea. As of early 2011

${ }^{20}$ Wedel, 2009. 
his Icelandic counterpart is still in the water, paddling hard but a long way from land, and the direction of the current is unclear.

The decision to make the creditors, not the taxpayers, shoulder the biggest share of bank losses was clearly a smart move - though as explained earlier those in charge would have done the opposite if they could. The government's and IMF's decision to postpone big cuts in public spending into 2010-2011 was also smart. As a result Iceland has so far experienced a smaller fall in GDP and employment and a faster rebound than the big public spending slashers like Ireland, Estonia and Latvia ${ }^{21}$. However, the government is undertaking drastic cuts in public spending in 2011. And the 2006 loan to double the foreign exchange reserves has to be repaid in 2011.

Then there is the looming Icesave debt. The debt to foreign depositors is equal to almost half of 2010 GDP. When the president, in 2010, called a referendum on the proposed Icesave repayment deal (only the second referendum in the history of the Icelandic republic), nine out of every ten Icelanders rejected it. A more favourable deal (to Iceland) is to be put to a new referendum. But many Icelanders believe that the debt should not be the liability of taxpayers, period, and that a wholesale restructuring of Iceland's debt is the only option - a "managed restructuring", avoiding the word "default". Equally, however, politicians in the UK and the Netherlands think that their taxpayers should not be liable to compensate Icesave depositors up to the European deposit guarantee scheme minimum; and that Iceland's taxpayers must assume the burden in order to protect the integrity of the whole European deposit guarantee scheme, even if repayments are stretched out over decades. These politicians have a whiphand over Iceland's destiny in the European Union. They threaten that Iceland must approve the new Icesave deal or suffer the wrath of the international community. Unfortunately for them, the first rejection was followed by a fall, not a rise, in the cost of credit default swaps on Iceland's sovereign debt, as investors heard renewed assurances that the government would honor its debt obligations (undefined).

The Special Investigation Commission established by parliament produced a remarkably full and honest account of the boom and bust, published in April 2010 in 9 volumes weighing $8 \mathrm{kilos}^{22}$. But hemmed in by commitment to the IMF programme, by demands from the public to write down household debts, and by intense lobbying from the Confederation of Employers saying (with substantial public support) "Time to move on", the government has in effect buried the SIC report. Indeed, the co-chairman of the Independence Party said in a TV program that "This [SIC] report is getting in our way, but just temporarily". Not a single government agency at home or abroad has asked one of the principals to give a talk about the report's findings, while the IMF, the Federal Reserve, all the Nordic central banks, the Bank of England, and more have issued invitations, all accepted (to which the relevant Icelandic embassies have declined even to send a staff member). After one of the

\footnotetext{
${ }^{21}$ Ólafsson and Kristjánsson, 2010; Wade, 2009.

${ }^{22}$ Special Investigation Commission, Causes and build up to the collapse of the Icelandic banks in 2008. Delivered to the Icelandic parliament, Althingi, April 12 ${ }^{\text {th }}, 2010$.
} 
principals spoke at the IMF in Washington, an Icelandic central bank official seconded to the IMF called her into his office and rebuked her for being "unpatriotic". Social scientists who talk and publish about Iceland's experience to foreign audiences are often accused in media and blogs of working against the national interest.

A special prosecutor has been at work since late 2008, with a staff of 60 by 2010, but has so far (early 2011) brought no charges. Lawyers defending the suspects constantly invoke "rules of bank secrecy" to delay or derail the cases. Luxembourg, the site of European operations for one of the Icelandic banks, has delayed and delayed releasing information to the special prosecutor. Under Icelandic law a prosecution which fails the first time cannot be brought again.

Privately, many in Iceland's elite think that, for all the short-term disruption, the boom was well worth the crash, both in terms of their personal situation and the national situation. They - their banks and private equity companies - managed to divert vast profits from foreign economic activity into tiny Iceland by dint of borrowing to buy foreign assets, enormously raising living standards and improving infrastructure. Whether the methods were legal or moral is a secondary matter (in the elite's eyes); afterall, the rest of the world let them get away with it. Their main concern now is to move on, not keep dwelling in the past, and to prevent the debt load from crashing living standards back down to where they were before the foreign borrowing started (and of course the financiers themselves are anxious to avoid prosecution and restart the game as memories fade, but now from bases in places like Malta, Luxembourg, and London). The main daily newspaper pushes this editorial line. Its editor is none other than David Oddsson, after he was fired from the central bank - the equivalent of Richard Nixon being made editor of the Washington Post during the Watergate investigation.

A new government with the Independence Party back in charge would be very helpful for the elite's purpose. The Independence Party, playing on short memories, is having success in persuading voters that the present government (which took office in April 2009) is the cause of their suffering, nothing to do with the Independence Party.

Independence Party machinations may lie behind the fate of the constitutional assembly. The present parliament agreed to sponsor elections for a constitutional assembly charged with drawing up a new constitution to replace the one inherited from the Danish Monarchy at the end of the Second World War; in effect, a constitution for the second Iceland Republic, based on a new social contract between citizens and the state. But the Supreme Court, four of whose five judges were appointed by the Independence Party, produced an assessment that the elections were invalid. The Independence Party has a strong interest in not allowing the assembly to operate. The court's assessment came out after it became clear that most of the assembly's members favoured constitutionalizing the principle that Iceland's natural resources (including water, fisheries etc.) belong to "the nation". Many in the political elite wish to be able to privatize natural resources in order to convert them from "dead capital" to "live capital" - for example, sell water sources to foreign bottling companies wanting to market "pure Icelandic water", or sell rivers to hydro-electric power companies; and conversely they fight against the idea of bringing the fishing quotas back to public ownership and periodically 
auctioning them, the revenues to be used for public purposes. At present (early 2011) the constitutional assembly remains in limbo.

Meanwhile, in the outside world, the critical issue of cross-border bank regulation, and in particular the non-viability of the distinction between "branches" and "subsidiaries", has hardly been addressed, even though this cuts at the foundations of the common European financial market. Nor the problem in the multilateral surveillance system illustrated by the fate of the IMF's strong "draft" warnings to the prime minister and finance minister in 2006 - that the IMF's assessment has to be negotiated with the government before public release. Still less has the outside world begun to address the root causes of global financial instability, of which Iceland is just one small manifestation; namely, the toxic combination of flexible exchange rates between the major currencies, the US dollar as the international reserve currency, and free capital movements.

\section{REFERENCES}

ÁRNASON, Örnólfur (1991) Á slóð Kolkrabbans; Hverjir eiga Ísland? Bókaútgáfan Skjaldborg. Reykjavík.

BLACK, William (2005) The Best Way to Rob a Bank is to Own One: How Corporate Executives and Politicians Looted the Savings and Loan Industry, Texas: University of Texas Press.

BLACK, William (2010) Public lecture at the University of Iceland, May $3^{\text {rd }}, 2010$.

BOYES, Robert (2009) Meltdown Iceland, London: Bloomsbury, 2009.

BURT, Tim (1998) "Iceland warms to offshore banking: PM wants country to emulate Luxembourg and Switzerland", Financial Times, April $7^{\text {th }} 1998$.

DANSKE BANK (2006) "Iceland: geyser crisis. Available at: <http://danskeanalyse.danskebank.dk/ link/FokusAndreIceland21032006/\$fi le/GeyserCrises.pdf>.

DAVIDSDOTTIR, Sigrun and Rowena MASON (2011) "Kaupthing approved $£ 1.69$ bn loans for Arsenal backer Alisher Usmanov prior to collapse”, Telegraph, January 20 ${ }^{\text {th }}, 2011$.

GISSURASON, Hannes (2004) “Miracle on Iceland”, Wall Street Journal, January 29th, 2004.

IMF - INTERNATIONAL MONETARY FUND (2006) Staff Report: Iceland, July 13 ${ }^{\text {th }}, 2006$.

IMF - INTERNATIONAL MONETARY FUND (2008) Iceland, Request for Stand-By Arrangement, November $25^{\text {th }}, 2008$. Available at: <http://www.sedlabanki.is/lisalib/getfile.aspx?itemid=6606) >.

LAFFER, Arthur (2007) “Overheating is not dangerous", Morgunbladid, November 17 2007.

MISHKIN, Frederic and Tryggvi P. HERBERTSSON, (2006) "Financial Stability in Iceland". Iceland Chamber of Commerce, Reykjavik 2006. After the crash the title of the paper mysteriously changed to "Financial instability in Iceland", as listed on his website. Available at: <http://www.vi.is/ files/555877819Financial\%20Stability\%20in \%20Iceland\%20Screen \%20Version.pdf $>$.

ÓLAFSSON, Stefán and Arnaldur Sölvi KRISTJÁNSSON (2010) "Income inequality in a bubble economy: The case of Iceland 1992-2008". Paper presented at the Luxemburg Incomes Study Conference, June 28-30 th 2010 (Paper). Available at: <http://www.lisproject.org/conference/papers/ olafsson-kristjansson.pdf $>$.

PORTES, Richard and Friðrik M. BALDURSSON (2007) “The internationalisation of Iceland's financial sector”, Iceland Chamber of Commerce. Reykjavik. Available at: <http:/www.iceland.org/ media/jp/15921776Vid4WEB.pdf>.

SPECIAL INVESTIGATION COMMISSION (2010) Causes and build up to the collapse of the Icelandic banks in 2008, Althingi, 2010, v. 1.

WADE, Robert (2009) "Iceland shows the dangers ahead for us all”, Financial Times, August 27th, 2009.

WEDEL, J. R. (2009) Shadow Elite: How the World's new Power Brokers Undermine Democracy, Government, and the Free Market, New York: Basic Books. 